\title{
Groundwater Condition and Management in Kano Region, Northwestern Nigeria
}

\author{
Abubakar Ibrahim Tukur 1,* (D), Aliyu Baba Nabegu ${ }^{1}$, Da'u Abba Umar ${ }^{2}$ (D), \\ Emmanuel Ajayi Olofin ${ }^{3}$ and Wan Nor Azmin Sulaiman ${ }^{4}$ \\ 1 Department of Geography, Kano University of Science and Technology, Wudil 713211, Nigeria; \\ aliyunabegu@gmail.com \\ 2 Department of Environmental Sciences, Federal University Dutse, Jigawa 720231, Nigeria; \\ abbaumar.d@fud.edu.ng \\ 3 Department of Water Resources Management and Agro-Meteorology, Federal University of Oye Ekiti, \\ Oye 371104, Nigeria; eaolofin@hotmail.com \\ 4 Faculty of Environmental Studies, Universiti Putra Malaysia UPM, Serdang 43400, Selangor, Malaysia; \\ wannor@upm.edu.my \\ * Correspondence: aitukur@hotmail.com; Tel.: +234-803-638-3808
}

Received: 30 December 2017; Accepted: 5 February 2018; Published: 9 February 2018

\begin{abstract}
This paper provides a broad overview of issues on groundwater condition and management in the Kano region of northwestern Nigeria. The aim is to recommend new management strategies that can ensure sustainable groundwater resource management in the region. To achieve the aim of the study, various studies on groundwater conducted in the region were reviewed and key issues were identified. The review revealed that groundwater availability varied between the Basement Complex and Chad Formation areas of the region, with the latter having more of the resource than the former region as a result of the migration of groundwater from the Basement complex to the Chad Formation region. The review also revealed a steady annual decrease of groundwater level during the period 2010 to 2013 and the groundwater beneath the floodplains dropped from 9000 Million Cubic Meter (MCM) in 1964 to 5000 MCM in 1987 in the Chad Formation area of the region. The review further revealed that there is poor knowledge regarding the impact of historical and projected climate variability and change on groundwater availability in the region. This is as a result of the lack of sustained time series data on groundwater resource. Thus, there has been little or no integrated management between groundwater excess and deficiency on one hand, and groundwater pollution management on the other hand. Rainwater harvesting, among other approaches, is recommended for sustainable groundwater management in the region.
\end{abstract}

Keywords: groundwater; climate variability; floodplain; condition; management; Dryland

\section{Introduction}

The importance of water to life on earth, particularly to human beings, becomes clearer when one considers its role or usefulness in various aspects of human endeavor [1]. As such water is at the centre of Sustainable Development Goals (SDGs) numbers 1, 3, 6 and 16 [2]. In many parts of the arid and semi arid regions, reliance on groundwater has increased significantly mainly due to inadequate rainfall and the consequent surface water scarcity [3]. Many people in developing countries particularly in Sub-Saharan regions generally rely on groundwater sources for potable water [4]. In many African countries such as Niger, Botswana, and Ghana, groundwater accounts for $71.43 \%, 50 \%$ and $47.56 \%$, respectively, of their total freshwater sources [5] and accounts for over $60.9 \%$ of the domestic supply in the Ejisu-Juaben municipality of the Ashanti Region of Ghana [6]. Similarly, groundwater is the main source of water to about 70\% of the inhabitants of Meru City, Tanzania [7]. Although groundwater 
accounts for only $28.90 \%$ of the total freshwater in Nigeria [5], about 128 million people $(85 \%$ of the total population) depended on this resource as at 2001 mainly due to the deterioration in the quality and quantity of surface water, insufficient water supply by water authorities, effect of climate change and above all rapid population growth [8]. In the northern part of Kano region, the interplay of hydrologic and geological characteristics makes surface water virtually inadequate, and as such groundwater appears to be the only reliable source of fresh water for domestic and agricultural use [9].

Although water is necessary for human survival, many urban areas of the world have been experiencing water shortages, which are expected to explode in this century unless serious measures are taken to reduce the scale of this problem [10]. In sub-Saharan Africa, at least $44 \%$ of the populations (about 320 million people) do not have access to clean reliable water supplies [11]. In the dry land regions, such as northwestern Nigeria, this problem of groundwater deterioration can be worsened by prolonged drought as a result of climate change and desertification process, and it is predicted that these regions will be under the threat of groundwater quantity and quality challenge in the near future [12].

Kano region in northwestern Nigeria is currently home to nearly $34 \%$ of the nation's population. The region covers seasonally humid and semi-arid regions accounting for $65 \%$ of the total population of northwestern regions [13]. However, natural and anthropogenic influences such as drought, desertification, rapid population growth, agricultural development coupled with pollution from industrial activities and domestic sewage have been identified as effective factors leading to imbalance between water supply and demand as well as the general quality of both surface and groundwater resources in the region [13]. It is worth mentioning that the region has not yet acknowledged the extent of the problems of water availability in the area. This is evidenced by the absence of any long-term strategies for water management. As such, balancing water availability and rising population (human demand) is the major challenge in the region.

Groundwater resource management has been identified as the contentious issue, principally in the dry land regions where rapid population growth and rainfall variability make the availability of surface water inadequate and the inadequacy adds more pressure to the existing groundwater resources. It is for this reason that this paper provides a broad overview of groundwater condition and management in the Kano region of northwestern Nigeria with a view of providing key issues regarding groundwater resources management that needs to be addressed. Specifically, the paper aims at

(i) Identifying areas with groundwater deficiency and challenges in the region;

(ii) Determining groundwater quality status in the region;

(iii) Recommending what should be the focus of groundwater management in the region.

It is hoped that the review will go some way towards assisting policy makers, institutions, and other stakeholders in addressing what remains the greatest challenge regarding groundwater management issues in the region.

\section{Materials and Methods}

\subsection{Geographical Background of Kano Region}

Kano region, according to [14], has been defined as the political States of Kano and Jigawa which previously constituted a single state. Kano regionis located in the dry land zone of Nigerian northwest (Figure 1). It is the most populous region in the whole of Nigeria and it is characterized by rainfall variability around a long-term annual total ranging from less than $600 \mathrm{~mm}$ in the northernmost parts to $800 \mathrm{~mm}$ in the middle (around Kano City) to $1000 \mathrm{~mm}$ in the southern tips. The duration of the wet season in that order ranges from 4 months in the northernmost through 5 months in the middle to 6 months in the southern tips during most of the years. The remaining months of the year are dry. The region extends over two major geological structures separated by an interface known as the 
hydrological divide (Figure 2). The southern and western parts of the Divide are underlain by the Basement Complex rocks and the northeastern parts by the sedimentary ChadFormation (Figure 2). The Basement Complex rocks consist mostly of igneous and metamorphic rocks with relatively shallow weathered mantle that permits very limited groundwater content. On the other hand, the Chad Sedimentary Formation consists largely of unconsolidated porous sandy sediments in which aquifers exist in three known layers, two top ones of which are accessible to borehole exploitation. Besides, there are alluvial deposits on river floodplains easily exploited for the groundwater through tube wells. Thus, the two major structures of the region have influenced the available groundwater quantity and variation in the region. That is, groundwater availability varied between the southern and northeastern region, with the latter having abundance of groundwater resource and the former with more of surface water resource [15]. In all the locations, the existing water resource management strategy is virtually inadequate; as such pressure is mounted on the available groundwater for various uses, principally in the northeastern part of the region. Figures 3 and 4 show the land use and elevation of the region, respectively.

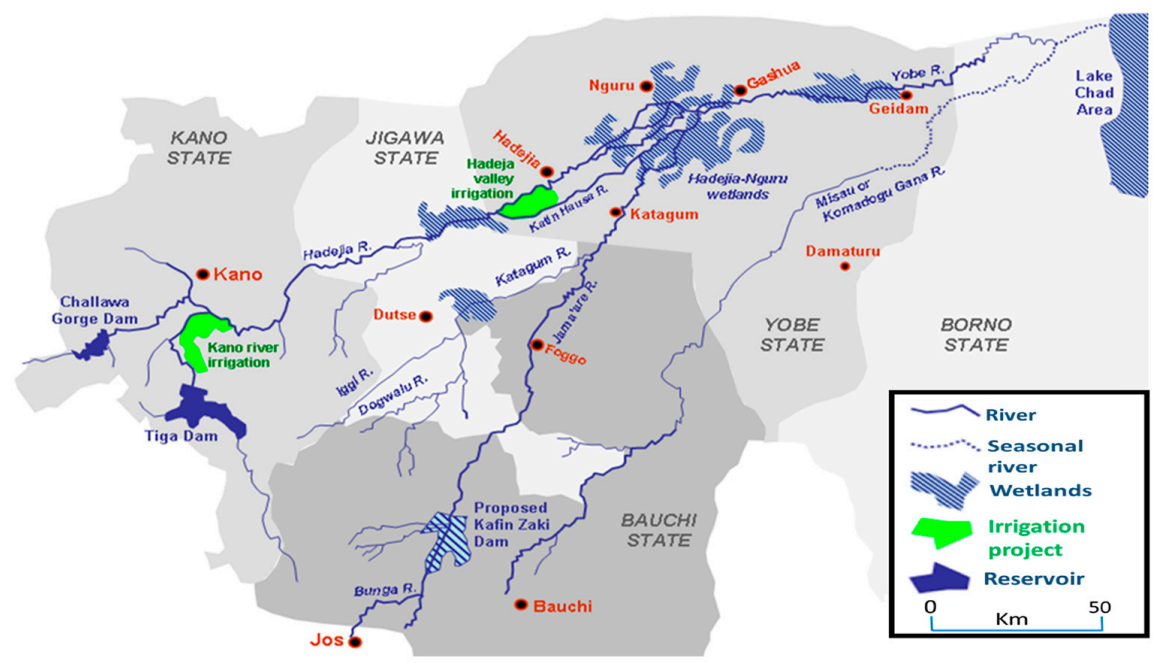

Figure 1. River Basins of Northern Nigeria.

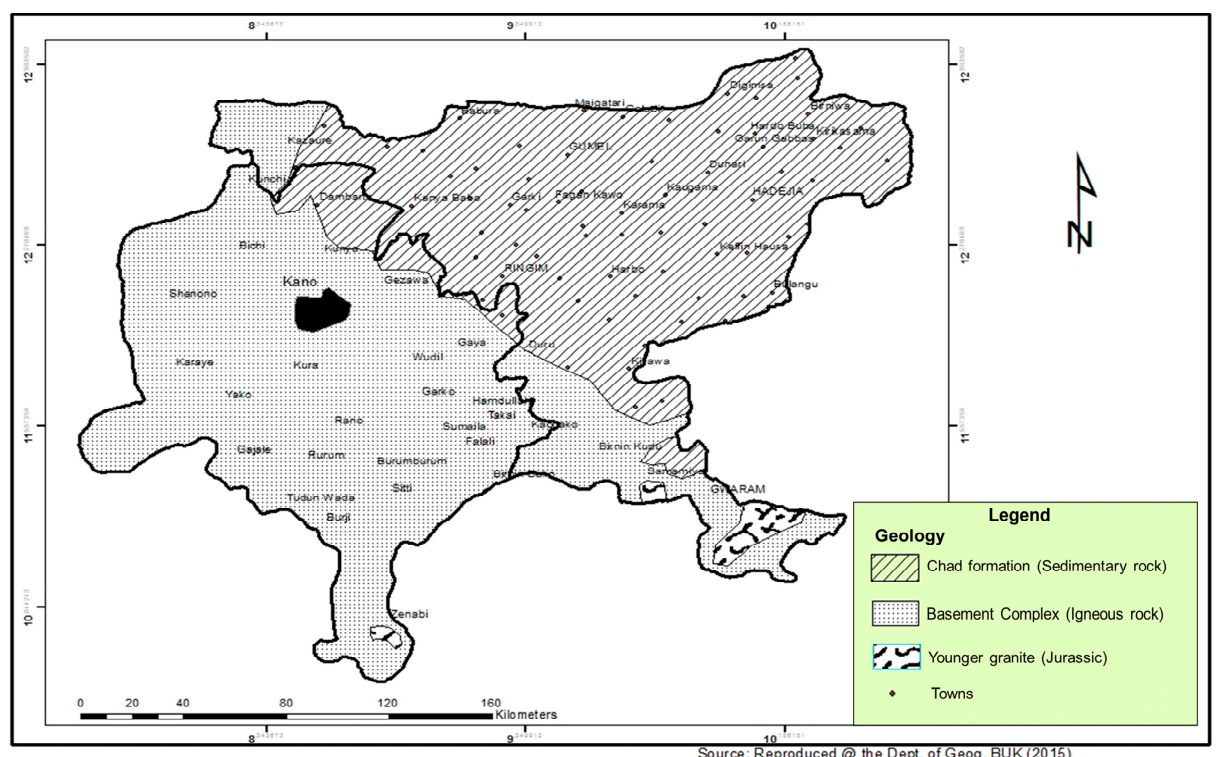

Figure 2. The Geology of Kano Region. 


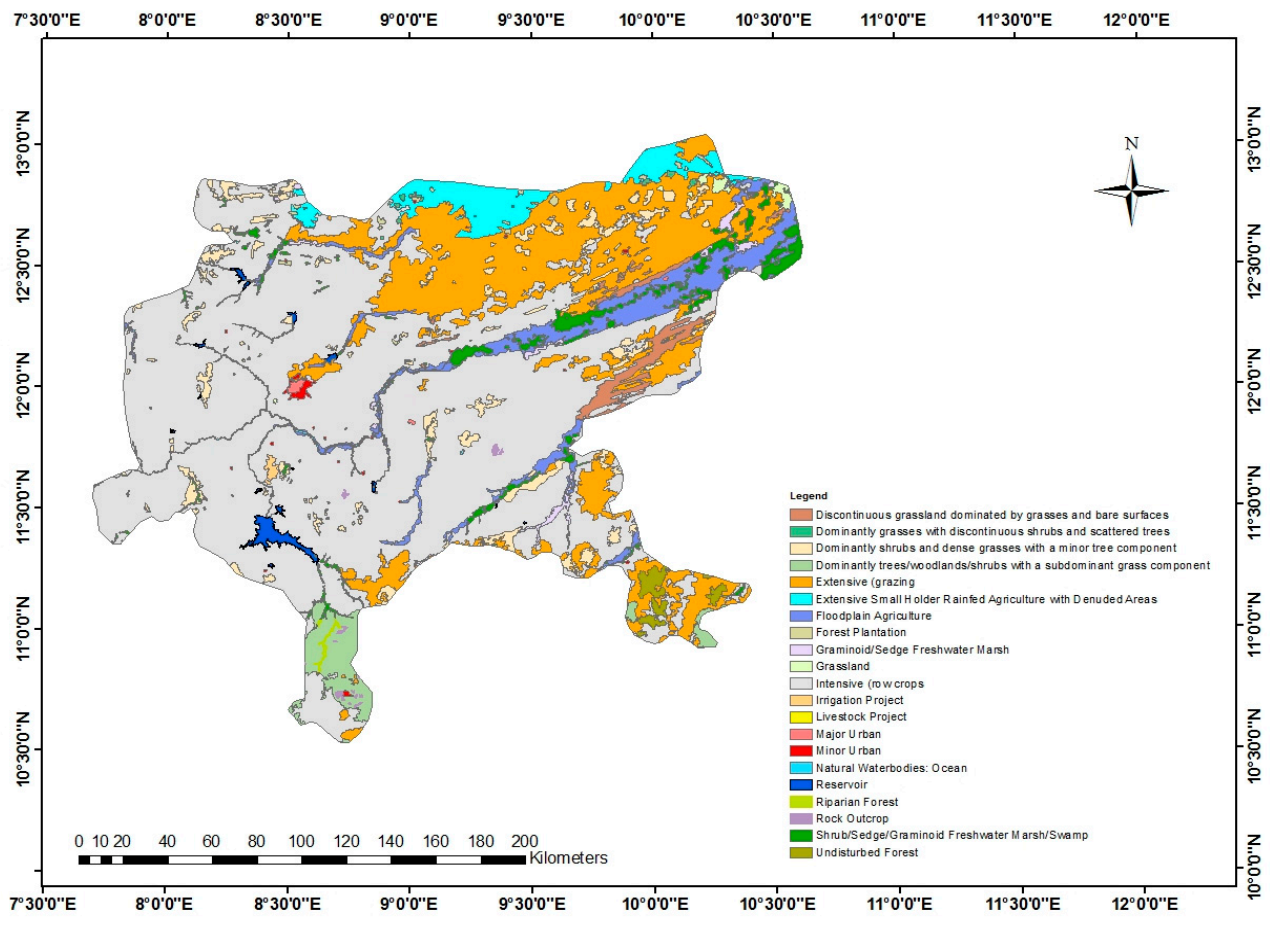

Figure 3. Land Use Map of Kano Region.

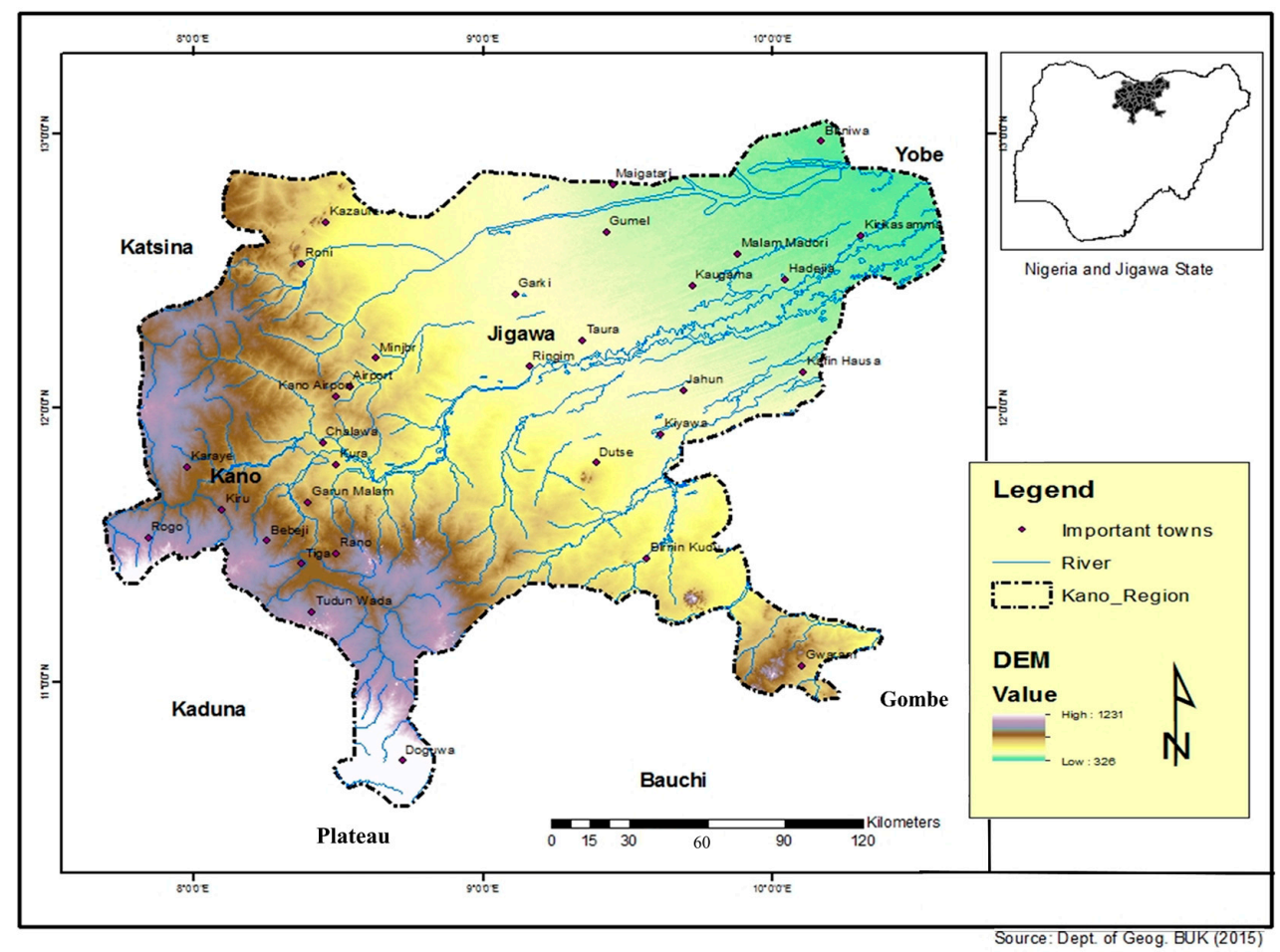

Figure 4. Elevation and Drainage of Kano Region.

\subsection{Methods}

A bibliographic survey based on Google Scholar Citation Index and the Science Citation Index Expanded (SCIE) database was conducted to evaluate groundwater-related research in the area covering different perspectives (Table 1). Further, a survey of groundwater yield and quality in the 
floodplain along the basin was conducted covering a transect of about $135 \mathrm{~km}$ during two distinctive seasons of one year (dry and rainy) to ascertain the findings of previous studies concerning the groundwater condition in the region. Six transects were established within one $\mathrm{km}^{2}$ of each selected point along the basin and were oriented perpendicular to the river channel. Three tube wells were sampled and positioned along each transect at regular intervals making a total of 18 wells. A pumping test, which was repeated four times at 15 min interval in both morning and evening hours was used to measure groundwater yield. The sampling standard methods prescribed by American Public Health Association [16] were followed carefully for the groundwater samples collection to determine the concentration of water quality indices presented in Table 2. Eleven water quality indices representing four hazard classes (Salinity hazard, Permeability/infiltration hazard, Specific ion toxicity hazard and Miscellaneous hazard) were used. They include Electrical Conductivity (EC), Sodium Absorption Ratio (SAR), Percent Sodium (\%Na), Kelly's Ratio (KR), Magnesium Hazard (MH), Permeability Index (PI), Boron (B), Chloride $\left(\mathrm{Cl}^{-}\right)$, Residual Sodium Carbonate (RSC), $\mathrm{pH}$ and Bicarbonate $\left(\mathrm{HCO}_{3}{ }^{-}\right)$. Six of the indices were computed using the equations below:

$$
\begin{gathered}
\% \mathrm{Na}=\left(\frac{\mathrm{Na}^{+}+\mathrm{K}^{+}}{\mathrm{Ca}^{2+}+\mathrm{Mg}^{2+}+\mathrm{Na}^{+}+\mathrm{K}^{+}}\right) \times 100 \\
\mathrm{SAR}=\frac{\mathrm{Na}^{+}}{\sqrt{\frac{\mathrm{Ca}^{2+}+\mathrm{Mg}^{2+}}{2}}} \\
\mathrm{RSC}=\left(\mathrm{CO}_{3}^{2-}+\mathrm{HCO}_{3}^{-}\right)-\left(\mathrm{Ca}^{2+}+\mathrm{Mg}^{2+}\right) \\
\mathrm{MH}=\left(\frac{\mathrm{Mg}^{2+}}{\mathrm{Ca}^{2+}+\mathrm{Mg}^{2+}}\right) \times 100 \\
\mathrm{PI}=\frac{\mathrm{Na}^{+}+\sqrt{\mathrm{HCO}_{3}}}{\mathrm{Ca}^{2+}+\mathrm{Mg}^{2+}+\mathrm{Na}^{+}} \times 100 \\
\mathrm{KR}=\left(\frac{\mathrm{Na}^{+}}{\mathrm{Ca}^{2+}+\mathrm{Mg}^{2+}}\right)
\end{gathered}
$$

A weighted arithmetic method was used in computing the Irrigation Water Quality Index (IWQI).Multivariate statistical tools such as analysis of variance, Pearson product moment correlation, and Cluster Analysis (CA) were used respectively, to test the research hypothesis and to classify sampling points into similar groups based on groundwater yield and dynamic level. 
Table 1. Summary of Reviewed Groundwater-related Studies in Kano Region.

\begin{tabular}{|c|c|c|c|c|c|}
\hline \multicolumn{6}{|c|}{ Groundwater-Related Studies in Kano Region } \\
\hline No. & Author (s) and Year & Research Objective and Location & Methodology & Research Findings & Comments \\
\hline 1 & $\begin{array}{l}\text { Tahir, et al. } \\
\text { (2015) [17] }\end{array}$ & $\begin{array}{l}\text { To assess the suitability of } \\
\text { groundwater for irrigation \& } \\
\text { domestic use in the Kano } \\
\text { metropolis, Nigeria. }\end{array}$ & $\begin{array}{l}\text { A total of } 20 \text { groundwater samples were } \\
\text { collected from deep and shallow } \\
\text { boreholes. Piper \&Wilcox diagramswere } \\
\text { used, respectively, to determine } \\
\text { hydrochemical facies\& suitability of } \\
\text { water for irrigation. }\end{array}$ & $\begin{array}{l}\text { Piper diagram identified Ca-Mg_SO as the } \\
\text { dominant water facie type. All the water } \\
\text { samples fall within the C1-S1 hazard class } \\
\text { based on a Wilcox plot. }\end{array}$ & $\begin{array}{l}\text { No rigorous statistical tools used to } \\
\text { support the result. }\end{array}$ \\
\hline 2 & $\begin{array}{l}\text { Abdulhamid, et al. } \\
\text { (2014) [18] }\end{array}$ & $\begin{array}{l}\text { To explore the missing link } \\
\text { between the increasing rainfall and } \\
\text { decreasing groundwater quantity } \\
\text { in the Kano Basement Complex, } \\
\text { Northwester Nigeria }\end{array}$ & $\begin{array}{l}\text { 30-year rainfall data was obtained from } \\
\text { global precipitation climatology center } \\
\text { (GPCC) website, while groundwater data } \\
\text { was obtained through field work. } \\
\text { Percent change was used to analyze } \\
\text { the data }\end{array}$ & $\begin{array}{l}\text { The result shows that rainfall trend has } \\
\text { been on the increase especially around the } \\
\text { Metropolitan Kano from the late 1990s to } \\
\text { date, with a corresponding decrease in } \\
\text { groundwater quantity. }\end{array}$ & $\begin{array}{l}\text { It is concluded that anthropogenic } \\
\text { activities especially groundwater } \\
\text { abstraction were identified as one of } \\
\text { major causes. }\end{array}$ \\
\hline 3 & $\begin{array}{l}\text { Abdulhamid, } \\
\text { (2014) [16] }\end{array}$ & $\begin{array}{l}\text { To evaluate surface and } \\
\text { groundwater resources in Kano } \\
\text { Region, Northwestern Nigeria }\end{array}$ & $\begin{array}{l}\text { Field work was undertaken to measure } \\
\text { groundwater yield, aquifer thickness and } \\
\text { volume covering } 11 \text { settlements. Data on } \\
\text { rainfall were obtained from Kano State } \\
\text { Water Board Office. }\end{array}$ & $\begin{array}{l}\text { Migration of groundwater from basement } \\
\text { complex to the sedimentary formation and } \\
\text { rising demand of water by the ever } \\
\text { increasing population, are among the } \\
\text { major challenge facing water resources } \\
\text { development in the area. }\end{array}$ & $\begin{array}{l}\text { Three tier management strategy is } \\
\text { proposed to address the existing water } \\
\text { resource management in the region. }\end{array}$ \\
\hline 4 & Tukur, (2017) [19] & $\begin{array}{l}\text { To evaluate the suitability of } \\
\text { groundwater for floodplain } \\
\text { irrigation along Hadejia River } \\
\text { Basin, Kano Region, } \\
\text { Northwestern Nigeria }\end{array}$ & $\begin{array}{l}\text { Data were collected through field work } \\
\text { in both dry and rainy seasons covering a } \\
\text { transect of about } 15 \mathrm{~km} \text {. A combination } \\
\text { of multivariate chemometric, GIS and \& } \\
\text { classical hydrochemical methods was } \\
\text { used to analyze the result }\end{array}$ & $\begin{array}{l}\text { Groundwater dynamic level and yield } \\
\text { decreases from the basement complex to } \\
\text { the Chad formation region. IWQI model } \\
\text { shows moderate }>\text { good }>\text { doubtful }> \\
\text { excellent of the groundwater suitability }\end{array}$ & $\begin{array}{l}\text { Groundwater suitability declines in the dry } \\
\text { season than in the rainy season based on } \\
\text { the four groundwater hazard classes }\end{array}$ \\
\hline 5 & $\begin{array}{l}\text { Mohammed, } \\
(2016)[20]\end{array}$ & $\begin{array}{l}\text { To assess the spatial variation of } \\
\text { groundwater yield and } \\
\text { vulnerability in the Kano Basement } \\
\text { Complex, Northwestern Nigeria }\end{array}$ & $\begin{array}{l}\text { Data on groundwater were obtained } \\
\text { from Kano Water Board office, } \\
\text { Kano State.GIS-based DRASTIC method } \\
\text { was used to present the result. }\end{array}$ & $\begin{array}{l}19 \% \text { of the area has no yield. } 42.5 \% \text { of the } \\
\text { underlain basement complex is fractured } \\
\text { with } 4 \% \text { unproductive. The static water } \\
\text { level was found between } 4.16 \text { and } 27.6 \mathrm{~m} \text {. }\end{array}$ & $\begin{array}{l}\text { Nitrate validation indicated a strong } \\
\text { relationship with DRASTIC model, } \\
\text { suggesting low groundwater quality in the } \\
\text { more polluted areas. }\end{array}$ \\
\hline 6 & $\begin{array}{l}\text { Garba, et al. } \\
(2016)[21]\end{array}$ & $\begin{array}{l}\text { To assess the hydrochemical } \\
\text { processes controlling groundwater } \\
\text { chemistry in Hadejia, Kano Region, } \\
\text { Northwestern Nigeria. }\end{array}$ & $\begin{array}{l}\text { Water samples was collected from } \\
20 \text { boreholes during rainy season. } \\
\text { A combination of cluster analysis (CA), } \\
\text { principal component analysis (PCA) and } \\
\text { pearson product moment correlation was } \\
\text { used to analyze the result }\end{array}$ & $\begin{array}{l}\text { Anthropogenic activities, mineralization } \\
\text { and weathering of geological deposits } \\
\text { were identified as the key actors } \\
\text { controlling groundwater chemistry } \\
\text { by PCA }\end{array}$ & $\begin{array}{l}\text { This suggests that the aquifer chemistry is } \\
\text { mainly controlled by TDS, } \mathrm{Mg}, \mathrm{NO}_{3}-, \mathrm{Cu} \text {, } \\
\mathrm{Cl}^{-} \text {, and } \mathrm{Mn} \text {, which indicates the origin of } \\
\text { major cations to be } \\
\text { dissolution/precipitation processes. }\end{array}$ \\
\hline
\end{tabular}


Table 1. Cont

\begin{tabular}{|c|c|c|c|c|c|}
\hline \multicolumn{6}{|c|}{ Groundwater-Related Studies in Kano Region } \\
\hline No. & Author (s) and Year & Research Objective and Location & Methodology & Research Findings & Comments \\
\hline 7 & $\begin{array}{l}\text { Sobowale, et al. } \\
\text { (2010) [22] }\end{array}$ & $\begin{array}{l}\text { To assess water resources } \\
\text { potentials of Hadejia River } \\
\text { Sub-Catchments in Kano Region, } \\
\text { Northwestern Nigeria }\end{array}$ & $\begin{array}{l}\text { The available water in the } \\
\text { sub-catchment was compared with } \\
\text { existing and potential water demand }\end{array}$ & $\begin{array}{l}\text { Results shows that about } 2619 \mathrm{MCM} \text { of } \\
\text { surface water is available annually } \\
\text { upstream of Wudil (HS 1), } 658 \mathrm{MCM} \text { is } \\
\text { available between Wudil and Hadejia } \\
\text { (HS 2), while } 905 \mathrm{MCM} \text { is available } \\
\text { between Hadejia and Gashua (HS 3). } \\
\text { Analysis of direct ground water recharge } \\
\text { revealed that } 86 \mathrm{~mm}, 94 \mathrm{~mm} \text { and } 8 \mathrm{~mm} \text { of } \\
\text { water is recharged to groundwater } \\
\text { annually in the three hydrological sections } \\
\text { HS } 1, \text { HS } 2 \text { and HS } 3 \text { respectively. }\end{array}$ & $\begin{array}{l}\text { Projections show that the water use rate } \\
\text { will reach } 100 \% \text { by } 2018\end{array}$ \\
\hline 8 & $\begin{array}{l}\text { Adamu, et al. } \\
\text { (2013) [23] }\end{array}$ & $\begin{array}{l}\text { To assess the suitability of } \\
\text { groundwater for drinking in the } \\
\text { Basement Complex area of } \\
\text { Kano, Nigeria. }\end{array}$ & $\begin{array}{l}\text { Twenty sample of groundwater were } \\
\text { collected from boreholes randomly } \\
\text { located in five different geological } \\
\text { settings (quartzite, granite, gneiss and } \\
\text { schist) of the area. Simple descriptive } \\
\text { statistics were used to present the result. }\end{array}$ & $\begin{array}{l}\text { The quality of the sampled water were } \\
\text { found to be within the WHO acceptable } \\
\text { limit for drinking. Rock-water } \\
\text { interaction \& weathering play a vital } \\
\text { role in the concentration of the } \\
\text { investigated parameters. }\end{array}$ & $\begin{array}{l}\text { No rigorous statistical tools used in } \\
\text { analyzing the data. }\end{array}$ \\
\hline 9 & Umar, (2016) [24] & $\begin{array}{l}\text { To identify groundwater level } \\
\text { fluctuation in Kano } \\
\text { Sedimentary formation area, } \\
\text { Northwester Nigeria }\end{array}$ & $\begin{array}{l}\text { Groundwater level data of } 4 \text { years were } \\
\text { obtained from the Hadejia River Basin } \\
\text { Development Authority, Kano office. } \\
\text { Simple descriptive statistics were used } \\
\text { in analyzing the data. }\end{array}$ & $\begin{array}{l}\text { There is steady decline of groundwater } \\
\text { level from } 2010 \text { to } 2013 \text {. }\end{array}$ & $\begin{array}{l}\text { Over-abstraction of groundwater coupled } \\
\text { with inadequate rainfall were identified as } \\
\text { the key factors for that. }\end{array}$ \\
\hline 10 & $\begin{array}{l}\text { Tasi'u, et al. } \\
\text { (2016) [25] }\end{array}$ & $\begin{array}{l}\text { To assess water supply situation in } \\
\text { rural Kano, Northwestern Nigeria }\end{array}$ & $\begin{array}{l}\text { The study was achieved through } \\
\text { in-depth interview with the inhabitants } \\
\text { in the rural areas of Kano state. }\end{array}$ & $\begin{array}{l}62.9 \% \text { of the respondents indicated } \\
\text { inadequacy of drinking water, with open } \\
\text { well accounting for } 41.4 \% \text { of the sources of } \\
\text { water in the area. }\end{array}$ & $\begin{array}{l}\text { The study recommends provision of bore } \\
\text { holes to address the inadequacy of } \\
\text { drinking water }\end{array}$ \\
\hline \multicolumn{6}{|c|}{ Groundwater-Related Studies outside Kano Region } \\
\hline 11 & $\begin{array}{l}\text { Rizwan, et al. } \\
\text { (2017) [26] }\end{array}$ & $\begin{array}{l}\text { To assess the effect of rainfall } \\
\text { factor on groundwater recharge in } \\
\text { Banghar Environs, India }\end{array}$ & $\begin{array}{l}\text { Statistical analysis such as mean, } \\
\text { median, mode and the co-efficient } \\
\text { standard deviation, co-efficient of } \\
\text { dispersion, co-efficient of variation and } \\
\text { co-efficient of skewness were used } \\
\text { to analyze the data. }\end{array}$ & $\begin{array}{l}\text { The years revealing more than the average } \\
\text { annual rainfall values indicate positive } \\
\text { recharge of groundwater trend and vice } \\
\text { versa. Cumulative departure exhibit } \\
\text { positive and negative trends and the } \\
\text { determination of moving rainfall average } \\
\text { provide a picture of cycle variation of } \\
\text { rainfall trend. }\end{array}$ & $\begin{array}{l}\text { It is suggests that implementation of a } \\
\text { rainfall augmentation scheme would } \\
\text { provide appropriate rainfall recharge to } \\
\text { the groundwater system and it would also } \\
\text { resolve the water crises problem }\end{array}$ \\
\hline
\end{tabular}


Table 1. Cont

\begin{tabular}{|c|c|c|c|c|c|}
\hline \multicolumn{6}{|c|}{ Groundwater-Related Studies outside Kano Region } \\
\hline No. & Author (s) and Year & Research Objective and Location & Methodology & Research Findings & Comments \\
\hline 12 & $\begin{array}{l}\text { Mastrocicco, et al. } \\
\quad(2011) \text { [27] }\end{array}$ & $\begin{array}{l}\text { To introduce good agricultural } \\
\text { practices that reduce the } \\
\text { amount of nitrate entering the } \\
\text { groundwater system }\end{array}$ & $\begin{array}{l}\text { The study was achieved through } \\
\text { quantification of kinetic control on } \\
\text { nitrate attenuation capacity. } \\
\text { The geochemical code PHREEQC } \\
\text { (version 2) was used to simulate kinetic } \\
\text { denitrification using Monod equation, } \\
\text { equilibrium, langmuir sorption of } \\
\text { acetate, and equilibrium reactionsof } \\
\text { gas and mineral phases (calcite). }\end{array}$ & $\begin{array}{l}\text { The reactive modeling results showed a } \\
\text { rapid acetate andnitrate mineralization } \\
\text { rate, implying that the main pathway of } \\
\text { nitrate attenuation is through } \\
\text { denitrification while calcite acted as a } \\
\text { buffer for pH. }\end{array}$ & $\begin{array}{l}\text { Reactive modeling is thought } \\
\text { to be an efficient and robust } \\
\text { tool to quantify the complex } \\
\text { biogeochemicalreactions which can take } \\
\text { place in undergroundenvironments }\end{array}$ \\
\hline 13 & $\begin{array}{l}\text { Colombani, et al. } \\
\text { (2016) [28] }\end{array}$ & $\begin{array}{l}\text { To quantify the present and } \\
\text { potential (2050) salinization of a } \\
\text { coastal aquifer in the Po Delta, Italy }\end{array}$ & $\begin{array}{l}\text { A combination of SEAWAT } 4.0 \text { and } \\
\text { PESTwas used for the prediction and } \\
\text { automatic inverse parameter } \\
\text { calibration, respectively. }\end{array}$ & $\begin{array}{l}\text { Results show that the Po Delta will } \\
\text { experience a significant salinization by } \\
2050 \text { and that the major cause is } \\
\text { autonomous salinization via seepage of } \\
\text { saline groundwater rather than enhanced } \\
\text { seawater intrusion due to sea level rise. }\end{array}$ & $\begin{array}{l}\text { This scenario allowed us to identify the } \\
\text { zones that are more affected by the relative } \\
\text { sea level rise and to quantify the increase } \\
\text { in salinization of groundwater. }\end{array}$ \\
\hline 14 & $\begin{array}{l}\text { Macdonald, et al. } \\
\text { (2012) [29] }\end{array}$ & $\begin{array}{l}\text { To present the first quantitative } \\
\text { maps of aquifer storage and } \\
\text { potential borehole yields in Africa }\end{array}$ & $\begin{array}{l}\text { The study made extensive review of } \\
\text { available maps, publications and data } \\
\text { on groundwater availability and } \\
\text { yield in Africa. }\end{array}$ & $\begin{array}{l}\text { Groundwater storage was estimated to be } \\
0.66 \text { million } \mathrm{km}^{3}\left(0.36-1.75 \text { million } \mathrm{km}^{3}\right) \text {. } \\
\text { The largest groundwater volumes are } \\
\text { found in the large sedimentary aquifers in } \\
\text { the North African countries Libya, Algeria, } \\
\text { Egypt and Sudan. }\end{array}$ & $\begin{array}{l}\text { Drilling of high yielding boreholes are } \\
\text { likely to be unsuccessful in rapidly } \\
\text { urbanizing cities, because the potential for } \\
\text { higher yielding boreholes }\left(>5 \mathrm{~L} \mathrm{~S}^{-1}\right) \text { is } \\
\text { much more limited }\end{array}$ \\
\hline 15 & $\begin{array}{l}\text { Taylor, et al. } \\
\text { (2009) [30] }\end{array}$ & $\begin{array}{l}\text { To review strategic research issues } \\
\text { pertaining to relationship between } \\
\text { groundwater and climate in Africa, } \\
\text { with a view to improving current } \\
\text { understanding of the impact of } \\
\text { climate on groundwater resources } \\
\text { in Africa }\end{array}$ & $\begin{array}{l}\text { The study was achieved through } \\
\text { review of } 96 \text { papers presented in the } \\
\text { Groundwater and Climate in } \\
\text { Africa Conference. }\end{array}$ & $\begin{array}{l}\text { Groundwater is well placed toenable } \\
\text { communities to adapt to changes in } \\
\text { freshwater demand and availability in } \\
\text { many parts ofAfrica, but substantial } \\
\text { uncertainty remains around the } \\
\text { development and management of } \\
\text { groundwater-based solutions. }\end{array}$ & $\begin{array}{l}\text { Future research on water resources and } \\
\text { climate change needs to focus on shorter } \\
\text { time scales and consider uncertainty } \\
\text { explicitly, providingquantitative } \\
\text { probability measures properly conditioned } \\
\text { on measured values of the variables }\end{array}$ \\
\hline 16. & $\begin{array}{l}\text { Tukur, et al. } \\
\text { (2016) [9] }\end{array}$ & $\begin{array}{l}\text { To evaluate methodological } \\
\text { approaches and trend in } \\
\text { groundwater quality studies across } \\
\text { developing countries }\end{array}$ & $\begin{array}{l}\text { Bibliographic survey of groundwater } \\
\text { quality studies covering } 13 \text { years } \\
\text { (2003-2016) across developing countries } \\
\text { was used to review both review and } \\
\text { article papers. }\end{array}$ & $\begin{array}{l}\text { Statistical approach }(29 \%) \text {, } \\
\text { hydro geochemical }(24 \%) \text { and GIS }(25 \%) \\
\text { methods are the dominant techniques used } \\
\text { and are being more utilized in the Asian } \\
\text { countries. There is generally poor } \\
\text { knowledge regarding groundwater } \\
\text { condition from floodplain aquifers of } \\
\text { Nigeria since the commencement of } \\
\text { shallow boreholes programme in } 1986\end{array}$ & $\begin{array}{l}\text { The use of Artificial Neural Network } \\
\text { (ANN), Structural Equation Modeling } \\
\text { (SEM), Decision Tree Models (DTM) and } \\
\text { numerical modeling such as MUDFLOW } \\
\text { were found to be lacking especially in } \\
\text { African countries. }\end{array}$ \\
\hline
\end{tabular}


Table 1. Cont

\begin{tabular}{|c|c|c|c|c|c|}
\hline \multicolumn{6}{|c|}{ Groundwater-Related Studies outside Kano Region } \\
\hline No. & Author (s) and Year & Research Objective and Location & Methodology & Research Findings & Comments \\
\hline 17 & $\begin{array}{l}\text { Adewuyi and Olofin } \\
\text { (2014) [31] }\end{array}$ & $\begin{array}{l}\text { To characterize the pattern of flood } \\
\text { incidences in the year } 2012 \text { across } \\
\text { Nigeria with the aim of } \\
\text { establishing the implications on } \\
\text { land degradation }\end{array}$ & $\begin{array}{l}\text { Data on flood incidences were obtained } \\
\text { from the Nigerian Metrological } \\
\text { Station.Simple descriptive statistics was } \\
\text { used in analyzing the data. }\end{array}$ & $\begin{array}{l}\text { The results revealed } 52 \text { major flood } \\
\text { incidences within } 88 \text { days: The spatial } \\
\text { distributions are: North Central } \\
\text { geopolitical zone recorded } 31 \% \text {, } \\
\text { South South } 21 \% \text {, North West } 17 \% \text {, } \\
\text { North East } 15 \% \text {, South East } 12 \% \text { and } \\
\text { South West } 4 \% \text { respectively }\end{array}$ & $\begin{array}{l}\text { The floods affected mostly states adjacent } \\
\text { to the major rivers and in manyinstances } \\
\text { aggravated land degradation }\end{array}$ \\
\hline 18 & Bakhari, (2014) [32] & $\begin{array}{l}\text { To assess the hydrogeochemical } \\
\text { process and anthropogenic factors } \\
\text { controlling groundwaterquality of } \\
\text { the upper unconfined aquifer } \\
\text { system of the Chad Basin, } \\
\text { Maiduguri, Nigeria. }\end{array}$ & $\begin{array}{l}\text { Twenty samples of groundwater were } \\
\text { collected from shallow tube wells located } \\
\text { in } 2 \text { different sites. ANOVA was used to } \\
\text { show the variation of the parameters } \\
\text { between the } 2 \text { sites }\end{array}$ & $\begin{array}{l}75 \% \& 25 \% \text { of The water samples were } \\
\text { found to be } \mathrm{Ca}-\mathrm{HCO}_{3} \& \mathrm{Na}-\mathrm{HCO}_{3} \text { water } \\
\text { type. Ion-exchange, silicate weathering } \\
\text { and calcium carbonate dissolution across } \\
\text { the basin are responsible for the } \\
\text { concentration of the major ions. } \\
\text { Concentration of nitrate, chloride, sulphate } \\
\text { \& phosphate were attributed to } \\
\text { agricultural and industrial activities }\end{array}$ & $\begin{array}{l}\text { The study could have used multivariate } \\
\text { statistical techniques such as PCA, } \\
\text { HACA and the likes to explain the result. }\end{array}$ \\
\hline 19 & $\begin{array}{l}\text { Fagbote, et al. } \\
\text { (2013) [33] }\end{array}$ & $\begin{array}{l}\text { To develop groundwater quality } \\
\text { index for drinking in Agbabu and } \\
\text { Temidire bitumen deposit area of } \\
\text { Ondo state, Nigeria. }\end{array}$ & $\begin{array}{l}\text { Groundwater samples from six boreholes } \\
\text { and hand dug wells were collected in dry } \\
\text { and rainy season of years } 2008 \text { and } 2009 . \\
\text { Entropy weighted methods was used in } \\
\text { determining the water quality index. }\end{array}$ & $\begin{array}{l}\text { WQI ranked all the groundwater samples } \\
\text { from wells as excellent and good in dry } \\
\text { and rainy seasons, respectively. }\end{array}$ & $\begin{array}{l}\text { The small number of samples did not } \\
\text { allow for geospatial mapping of WQI in } \\
\text { the study area. }\end{array}$ \\
\hline 20 & $\begin{array}{l}\text { Obiefuna \& Sheriff } \\
\text { (2011) [34] }\end{array}$ & $\begin{array}{l}\text { To assess the shallow groundwater } \\
\text { quality for irrigation \& domestic } \\
\text { purpose of Pindiga area, } \\
\text { Gombe State, Northeastern Nigeria }\end{array}$ & $\begin{array}{l}\text { A total of } 15 \text { groundwater samples were } \\
\text { collected from hand dug wells taping } \\
\text { shallow aquifer during rainy season. } \\
\text { Irrigation water quality indices (EC, TDS, } \\
\text { SAR, MAR, PI, KR, SSP \& RSBC) were } \\
\text { computed to assess water suitability } \\
\text { for irrigation. }\end{array}$ & $\begin{array}{l}\text { All water quality indices for irrigation } \\
\text { of thesampled water fall within the } \\
\text { permissible level indicating low } \\
\text { sodic waters. }\end{array}$ & $\begin{array}{l}\text { The study could have used geospatial tool } \\
\text { to map the distribution of groundwater } \\
\text { quality indices in the study area. }\end{array}$ \\
\hline 21 & $\begin{array}{c}\text { Obiefuna \& } \\
\text { Orazulike (2011) [35] }\end{array}$ & $\begin{array}{l}\text { To map groundwater facie of Yola } \\
\text { area, Northeastern Nigeria }\end{array}$ & $\begin{array}{l}\text { A total of } 27 \text { groundwater samples } \\
\text { were collected. }\end{array}$ & $\begin{array}{l}\text { Chloride-sulphate \& bicarbonate were } \\
\text { found to be the dominant water facie, } \\
\text { indicating dissolution and/or weathering } \\
\text { of minerals along the flow paths }\end{array}$ & $\begin{array}{l}\text { Geospatialt \& geochemical techniques } \\
\text { would have been better in presenting } \\
\text { the result. }\end{array}$ \\
\hline
\end{tabular}


Table 1. Cont

\begin{tabular}{|c|c|c|c|c|c|}
\hline \multicolumn{6}{|c|}{ Groundwater-Related Studies outside Kano Region } \\
\hline No. & Author (s) and Year & Research Objective and Location & Methodology & Research Findings & Comments \\
\hline 22 & Adelana, (2006) [36] & $\begin{array}{l}\text { To determine the distribution, } \\
\text { sources \& implications of nitrate } \\
\text { concentration from the } \\
\text { groundwater of Nigerian aquifers. }\end{array}$ & $\begin{array}{l}\text { Groundwater samples covering 2, } \\
200 \& 350 \text { wells from } 1985 \text { to } 2004 \text { and } \\
\text { pre-1970, respectively, were collected } \\
\text { through staff-students research } \\
\text { project and from the Geological } \\
\text { Survey of Nigeria. }\end{array}$ & $\begin{array}{l}\text { High concentration of } \mathrm{NO}_{3}(>1000 \mathrm{mg} / \mathrm{L}) \\
\text { occurred more in the sedimentary basins } \\
\text { in areas with intense agricultural \& } \\
\text { fertilizer application than in the basement } \\
\text { complex aquifers }(<5 \mathrm{mg} / \mathrm{L}) \text {. }\end{array}$ & $\begin{array}{l}\text { No rigorous analysis of data to support the } \\
\text { finding of the study. }\end{array}$ \\
\hline 23 & $\begin{array}{l}\text { Boukari and } \\
\text { Alassane, (2006) [37] }\end{array}$ & $\begin{array}{l}\text { To minimize the quality \& quantity } \\
\text { deterioration of aquifer water } \\
\text { resources in Benin City, Nigeria }\end{array}$ & $\begin{array}{l}\text { DRASTIC model with graphical methods } \\
\text { were used respectively in presenting } \\
\text { groundwater vulnerability \& } \\
\text { quality status }\end{array}$ & $\begin{array}{l}\text { Piper diagram identified the water as } \\
\text { Na-Cl water type with concentration } \\
\text { within the acceptable limit. Result from } \\
\text { DRASTIC model indicate moderate } \\
\text { vulnerable to vulnerable }\end{array}$ & $\begin{array}{l}\text { No rigorous statistics to support \& validate } \\
\text { the result of DRASTIC model }\end{array}$ \\
\hline 24 & $\begin{array}{l}\text { Graham, et al. } \\
\text { (2006) [38] }\end{array}$ & $\begin{array}{l}\text { To assess the suitability of } \\
\text { groundwater for irrigation in the } \\
\text { southwestern Sokoto Rima } \\
\text { Basin, Nigeria. }\end{array}$ & $\begin{array}{l}\text { A total of } 40 \text { groundwater samples were } \\
\text { collected from open wells, tube wells \& } \\
\text { boreholes in } 4 \text { different locations. } \\
\text { Simple descriptive statistics were used } \\
\text { to explain the result. }\end{array}$ & $\begin{array}{l}\text { The quality of water appeared to have no } \\
\text { salinity \& sodicity hazard. }\end{array}$ & $\begin{array}{l}\text { No rigorous statistical tools used in } \\
\text { analyzing the data. }\end{array}$ \\
\hline 25 & $\begin{array}{l}\text { Nakoma, et al. } \\
\quad(2016)[4]\end{array}$ & $\begin{array}{l}\text { To evaluate the suitability of } \\
\text { groundwater for domestic use in } \\
\text { Mzimba, northern Malawi. }\end{array}$ & $\begin{array}{l}\text { Groundwater samples were collected in } \\
\text { triplicate from } 20 \text { randomly selected } \\
\text { boreholes located in five villages. PCA, } \\
\text { one-way ANOVA \& LSD statistical } \\
\text { methods were used respectively to detect } \\
\text { correlation among the parameters, } \\
\text { establish differences \& make multiple } \\
\text { comparisons between the variables. }\end{array}$ & $\begin{array}{l}\text { The level of water pollution in all the } \\
\text { locations is generally no significant }\end{array}$ & $\begin{array}{l}\text { Recommended for spatio-temporal } \\
\text { assessment and microbiological analysis } \\
\text { of groundwater. }\end{array}$ \\
\hline 26 & $\begin{array}{l}\text { Mehra, et al. } \\
\text { (2016) [39] }\end{array}$ & $\begin{array}{l}\text { To assess groundwater quality, } \\
\text { potentials \& vulnerability for } \\
\text { agricultural use in the Mewat } \\
\text { district of Haryana, India }\end{array}$ & $\begin{array}{l}\text { Groundwater quality, potentials \& } \\
\text { vulnerability were determined using } \\
\text { weighted index, weighted overlay \& } \\
\text { DRASTIC method, respectively. } \\
\text { Multivariate clustering was used to } \\
\text { integrate the result of groundwater } \\
\text { quality, potentials \& vulnerability. }\end{array}$ & $\begin{array}{l}\text { The study generated map with } 5 \text { zones } \\
\text { based on groundwater quality, potentials \& } \\
\text { vulnerability, with zone } 1 \text { being the best } \\
\text { area for agriculture characterized with god } \\
\text { quality water, moderate water potential \& } \\
\text { lesser vulnerability to contaminants }\end{array}$ & $\begin{array}{l}\text { The study provides asound basis } \\
\text { for the planning of sustainable } \\
\text { groundwaterresources management } \\
\text { for agriculture }\end{array}$ \\
\hline
\end{tabular}


Table 1. Cont

\begin{tabular}{|c|c|c|c|c|c|}
\hline \multicolumn{6}{|c|}{ Groundwater-Related Studies outside Kano Region } \\
\hline No. & Author (s) and Year & Research Objective and Location & Methodology & Research Findings & Comments \\
\hline 27 & $\begin{array}{l}\text { Kumar, et al. } \\
\text { (2007) [3] }\end{array}$ & $\begin{array}{l}\text { To identify seasonal variation of } \\
\text { groundwater suitability for } \\
\text { irrigation \& drinking purpose } \\
\text { between two irrigated regions of } \\
\text { Punjab, India }\end{array}$ & $\begin{array}{l}15 \text { groundwater samples were collected } \\
\text { from each district in both dry and wet } \\
\text { season. Sampled wells were selected } \\
\text { based on difference in geology, landuse } \\
\text { and aquifer depth in each region. } \\
\text { Interview with } 10 \text { villagers from each } \\
\text { district was carried out to measure } \\
\text { their perception on test \& color } \\
\text { of groundwater }\end{array}$ & $\begin{array}{l}\text { Groundwater is suitable for irrigation \& } \\
\text { drinking in most of the locations with } \\
\text { excessive leaching, dilution \& flushing } \\
\text { of minerals in the Muktsar \& Patiala } \\
\text { village, respectively }\end{array}$ & No rigorous statistics \& GIS analysis used \\
\hline 28 & $\begin{array}{l}\text { Gereish, et al. } \\
\text { (2015) [40] }\end{array}$ & $\begin{array}{l}\text { To assess implications of climate } \\
\text { change on groundwater flow } \\
\text { regime \& geochemistry } \\
\text { of the Pleistocene aquifer, } \\
\text { Nile Delta, Egypt }\end{array}$ & $\begin{array}{l}\text { Hydrogeological field survey was } \\
\text { carried out for measuring water depth \& } \\
\text { collection of } 78 \text { samples of groundwater } \\
\text { from wells for hydrochemical analysis. } \\
\text { Stable isotope method was used to map } \\
\text { the groundwater flow direction \& } \\
\text { major hydrochemical facie of the } \\
\text { groundwater samples. }\end{array}$ & $\begin{array}{l}\text { Groundwater chemical composition } \\
\text { was attributed not to sea level rise \& } \\
\text { seawater intrusion, but rather the } \\
\text { geochemical process including a } \\
\text { combination of salt dissolution, ion } \\
\text { exchange \& evaporation. The salinity } \\
\text { distribution of the two aquifers is highly } \\
\text { conformable with the groundwater flow } \\
\text { map. The groundwater facie was } \\
\text { identified as } \mathrm{Ca}-\mathrm{HCO}_{3}, \mathrm{NaHCO}_{3} \text {-Na-mix } \\
\text { fresh water type }\end{array}$ & $\begin{array}{l}\text { The naturally imported Nile water is } \\
\text { thought as the main source of recharge for } \\
\text { the whole groundwater in the Nile Delta \& } \\
\text { surrounding desert. }\end{array}$ \\
\hline 29 & $\begin{array}{l}\text { Sappa, et al. } \\
\text { (2015) [41] }\end{array}$ & $\begin{array}{l}\text { To identify the factors influencing } \\
\text { and assess seasonal changes of } \\
\text { groundwater composition in the } \\
\text { coastal aquifers of Tanzania. }\end{array}$ & $\begin{array}{l}\text { Pattern diagrams, geochemical modeling } \\
\text { techniques and PCA were used to } \\
\text { identify the main factors affecting } \\
\text { groundwater composition from } 72 \text { wells } \\
\text { of the study area. }\end{array}$ & $\begin{array}{l}\text { The groundwater falls into the category } \\
\text { C2-S1,C3-S1, C3-S2, C4-S2. PCA revealed } \\
\text { seawater intrusion, evaporation\& } \mathrm{NO}_{3} \text { as } \\
\text { the major factors influencing the } \\
\text { groundwater chemistry }\end{array}$ & $\begin{array}{l}\text { SEM as an advancement of PCA can be } \\
\text { used to support the result of the study. }\end{array}$ \\
\hline 30 & $\begin{array}{l}\text { Sharma \& Chhipa, } \\
\text { (2013) [42] }\end{array}$ & $\begin{array}{l}\text { To provide water quality index for } \\
\text { Jaipur city of India }\end{array}$ & $\begin{array}{l}\text { Groundwater samples were collected } \\
\text { from } 12 \text { villages of the study area in dry } \\
\text { season. CC, WQI \& WHO were used to } \\
\text { analyze \& compare the obtained result } \\
\text { with the standards, respectively }\end{array}$ & $\begin{array}{l}\text { Result of WQI classifies the water under } \\
\text { poor quality (123.76) for drinking purpose. } \\
\text { CC revealed high correlation between EC } \\
\text { \& TDS ( } 0.996) \text {, indicating high salinity } \\
\text { level in the water }\end{array}$ & $\begin{array}{l}\text { Recommended to carry out a similar study } \\
\text { in the rainy season with a view of finding } \\
\text { variation in the water quality. }\end{array}$ \\
\hline 31 & $\begin{array}{l}\text { Barbiero, et al. } \\
\text { (2002) [43] }\end{array}$ & $\begin{array}{l}\text { To investigate the level of } \\
\text { variability and associated process } \\
\text { of salinity in the wetland of the } \\
\text { nhecolandia, pantanal of mato } \\
\text { grosso, Brazil }\end{array}$ & $\begin{array}{l}\text { A total number of } 41 \text { samples were taken } \\
\text { from groundwater between } 1994 \text { and } \\
\text { 1999. PCA, CC \& Piper diagram were } \\
\text { used to explain the result. }\end{array}$ & $\begin{array}{l}\text { PCA identified evaporation as the } \\
\text { principal process controlling groundwater } \\
\text { chemistry. Piper diagram classified the } \\
\text { water as } \mathrm{Na}^{+} / \mathrm{HCO}_{3} \text { water type. }\end{array}$ & $\begin{array}{l}\text { Recommended to focus on water \& solute } \\
\text { flows in the wetland of the area. }\end{array}$ \\
\hline
\end{tabular}


Table 2. Irrigation water standards, weight coefficient and relative weight of the hydrochemical parameters for IWQI.

\begin{tabular}{|c|c|c|c|c|c|}
\hline Hazard Groups & Parameters & Unit & $\begin{array}{c}\text { Maximum Permissible Limit } \\
\text { (FAO, 1998) }\end{array}$ & Weight; $\mathbf{w}_{\mathbf{i}}$ & Relative Weight; $\mathbf{W}_{\mathbf{i}}=\frac{\mathbf{w}_{\mathbf{i}}}{\sum_{\mathbf{i}=1}^{\mathbf{n}} \mathbf{w}_{\mathbf{i}}}$ \\
\hline Salinity Hazard & $\mathrm{EC}$ & $\mu S \mathrm{~cm}^{-1}$ & 3000 & 5 & 0.1316 \\
\hline \multirow{5}{*}{ Permeability/Infiltration Hazard } & SAR & meq $\mathrm{L}^{-1}$ & 26 & 4 & 0.1053 \\
\hline & $\% \mathrm{Na}$ & meq $L^{-1}$ & 80 & 4 & 0.1053 \\
\hline & $\mathrm{KR}$ & meq $\mathrm{L}^{-1}$ & 1 & 4 & 0.1053 \\
\hline & MH & meq $\mathrm{L}^{-1}$ & 50 & 4 & 0.1053 \\
\hline & PI & meq $\mathrm{L}^{-1}$ & $25 \%$ & 4 & 0.1053 \\
\hline \multirow[t]{2}{*}{ Specific Ions Toxicity Hazard } & $\mathrm{Cl}^{-}$ & $\mathrm{mg} \mathrm{L}^{-1}$ & 350 & 3 & 0.0789 \\
\hline & RSC & meq $\mathrm{L}^{-1}$ & 2.5 & 3 & 0.0789 \\
\hline \multirow{3}{*}{ Miscellaneous Hazard } & $\mathrm{pH}$ & - & 8.5 & 2 & 0.0526 \\
\hline & $\mathrm{HCO}_{3}{ }^{-}$ & $\mathrm{mg} \mathrm{L}^{-1}$ & 500 & 2 & 0.0526 \\
\hline & & & & $\sum \mathbf{w}_{\mathbf{i}}=38$ & $\sum \mathbf{W}_{\mathbf{i}}=\mathbf{1 . 0 0 0 0}$ \\
\hline
\end{tabular}




\section{Results}

\subsection{Concept of Water Resources Management}

The principal need for water resources management is primarily due to the fact that the hydrological cycle does not adapt itself to man's requirements for water over space or time. Consequently, water is usually not available in the quantity and quality required and at the time it is needed. Thus, strategies are put in place to develop and manage water in a manner that will make it available in the quantity and quality required and in the place and time it is needed [44]. The objective of water resource management in any region therefore is to achieve satisfaction between water availability and demand in both space and time through the modification of the hydrological cycle [45]. This involves not only the beneficial use of water resources, but also the prevention, avoidance or minimization of the effects of either water deficiency (drought), water excess (flood), water pollution or both.

\subsection{Groundwater Availability and Uses}

Groundwater availability varied in the region. Various factors affect its availability. The most recognized and important one is the geological differences. In his study [16], revealed that, the volume of groundwater decreases from the Chad Formation to the Basement Complex region, with Birniwa area in the former region and Zarewa in the later region having a respective volume of $9,363.0 \mathrm{~m}^{3}$ and $49.0 \mathrm{~m}^{3}$ of groundwater. Thus, groundwater availability is much higher in the Chad Formation than in the Basement Complex. The Chad Formation in the Kano region is one of the largest accessible stores of fresh groundwater, and for that groundwater is often considered a logical resource in the region. Conversely, in the Basement Complex region, rapid rising population growth in association with urbanization and change in climate have led to intensive exploitation of groundwater through construction of boreholes, principally for domestic water supply. Groundwater in the urban Kano area for instance appears to be a common and low-cost alternative to surface water for many uses because it occurs generally in a more potable quality compared to surface water. However, despite the growing dependency upon groundwater for different uses in urban Kano, concerns remain over the sustainability of this resource principally in terms not only of the rate of abstraction but also in terms of the quality and quantity because the area is underlain by igneous structure.

The uses of groundwater in the region varied from commercial, domestic and agricultural uses. In the northeastern part of the region, groundwater is the only source of fresh water for various domestic uses. Similarly, the resource appeared to be the only alternative and reliable source of water for various agricultural activities, especially, the floodplain (fadama) irrigation agriculture. While rain-fed agriculture lasts for about three to four months in the area, floodplain irrigation is well practiced throughout the dry season lasting for six to nine months. Thus, groundwater from fadama aquifer is extracted by tube wells and wash bores to support irrigation in the dry season from the end of the rainy season, which provides opportunities in terms of agricultural diversification than in the southern region and enables for double or triple cultivation in one single year. In the southern part of the region, however, groundwater becomes virtually the most reliable source of fresh water for domestic and commercial activities. Increase in the level of demand and consumption of water leads to the drilling of boreholes by individuals, government and private companies. Consequently, thousands of commercial water companies have emerged increasingly particularly in the urban areas of the region to exploit principally groundwater as the main source of potable water. The reliance of groundwater this way is a result of the inefficiency of the personnel of Water Works who are responsible for treating surface water for distribution to users, more so since the pipes and taps for such distribution are virtually permanently dry and the ponds, lakes and rivers are highly polluted. In addition, existing and newly constructed houses in the residential locations also rely on this resource as the reliable source of freshwater for their domestic use. 


\subsection{Groundwater Depletion}

The findings of [46], on groundwater availability in the region, revealed that the mean groundwater recharge contributed by river flow and rainfall accounted for 33\% and 13\%, respectively. The study further revealed, according to [19], that groundwater beneath the floodplains dropped from $9000 \mathrm{MCM}$ in 1964 to $5000 \mathrm{MCM}$ in 1987 (a drop of about one half of its initial value). In the same development, the finding of [47] on the variation of groundwater level in the same northern region of Kano revealed a positive relationship between rainfall and groundwater level variation. Thus, the study revealed a steady annual decrease of groundwater level from 2010 to 2013 in the area (Figure 5).

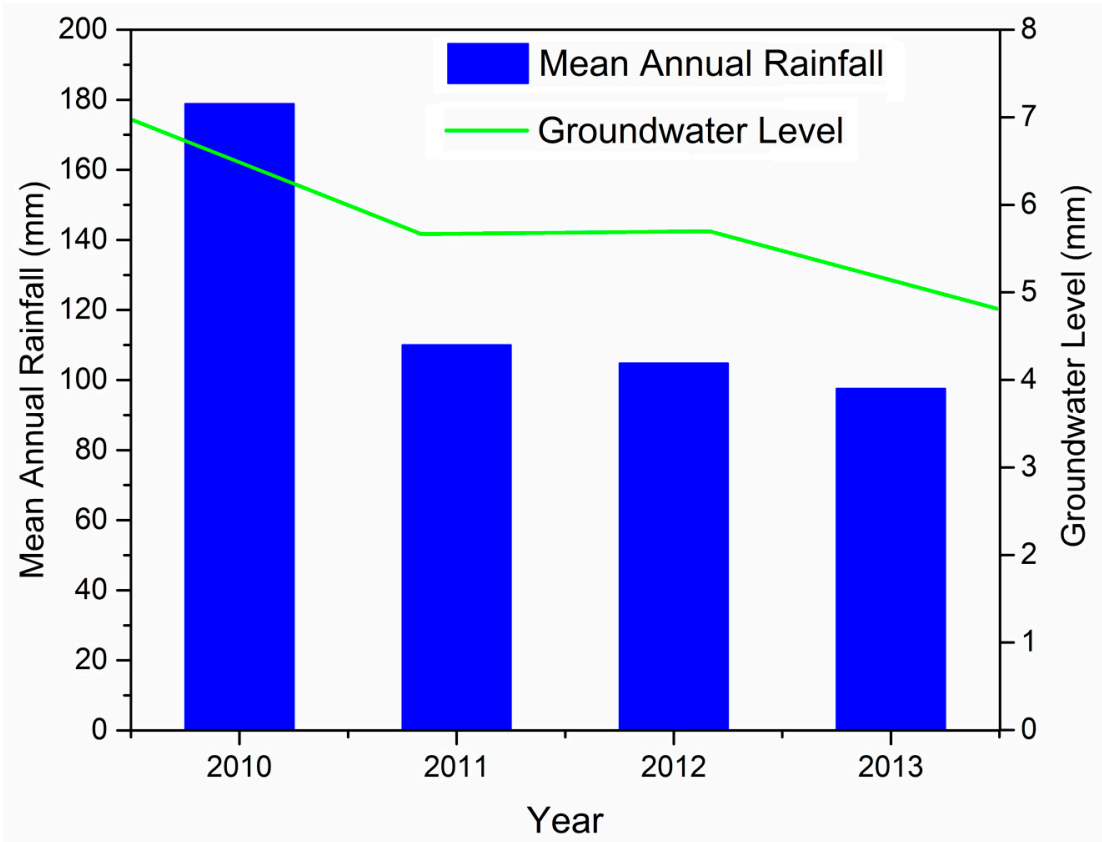

Figure 5. Annual trend of rainfall and groundwater level in the Hadejia.

Similarly, the finding of [16] projected groundwater deficiency in the southern Kano region as the resource was found to be migrating to the north eastern part of the region. In addition to this, rapid rising population growth coupled with the poor knowledge regarding the relationship between current climate variability and groundwater availability all can lead to groundwater deficiency in the region.

In the same development, the finding of [25] revealed that, groundwater average yield in the fadama land of the region was found to be within the standard $(2.5 \mathrm{~L} / \mathrm{s})$ for irrigation (Table 3). Although, yield in some locations, particularly, in Miga and Auyo haveminimum average yields of 0.5 and $1.3 \mathrm{~L} / \mathrm{s}$, respectively, which are considered unsuitable for irrigation. Overexploitation of the aquifer due to intensive irrigation activities can be a reason for this lowest yield, as Auyo and Miga are among the leading fadama irrigation towns, after Hadejia. Moreover these locations coincided with the towns where tube wells were built by the Macdonald and Diyam Consulting Company in 1962 over three decades now. Average yield of wells for evening hours recorded higher yield (56\%) than the yield in morning hours (44\%), in the region with the result of 2-way ANOVA showing significant diurnal variation $(p$ value $0.00<0.05)$ in the yield of wells. Furthermore, correlation test showed significant relationship between groundwater dynamic level and yield among the study locations ( $p$ value, $0.045<0.05)$. 
Table 3. Diurnal variation of groundwater yield along Hadejia River Basin.

\begin{tabular}{|c|c|c|c|c|c|c|c|c|c|c|c|c|}
\hline \multirow{3}{*}{ Time } & \multicolumn{10}{|c|}{ Diurnal Variation of Groundwater Yield (L/s) } & \multirow{3}{*}{$\begin{array}{c}\text { Total } \\
\text { Average }\end{array}$} & \multirow{3}{*}{$\%$} \\
\hline & \multicolumn{2}{|c|}{ Ringim } & \multicolumn{2}{|c|}{ Miga } & \multicolumn{2}{|c|}{ Auyo } & \multicolumn{2}{|c|}{ Hadejia } & \multicolumn{2}{|c|}{ Guri } & & \\
\hline & Range & Average & Range & Average & Range & Average & Range & Average & Range & Average & & \\
\hline Morning & $2.0-3.3$ & 2.58 & $0.5-3.5$ & 2.4 & $1.3-3.4$ & 2.6 & $1.9-3.4$ & 2.6 & $1.8-3.2$ & 2.5 & 12.68 & 44 \\
\hline Evening & $3.0-5.3$ & 3.78 & $0.5-4.5$ & 3.0 & $1.6-4.0$ & 3.2 & $2.3-4.0$ & 3.3 & $2.5-3.7$ & 2.9 & 16.18 & 56 \\
\hline Total & $2.0-5.3$ & 6.36 & $0.5-4.5$ & 5.4 & $1.3-4.0$ & 5.8 & $1.9-4.0$ & 5.9 & $1.8-3.7$ & 5.4 & 28.86 & 100 \\
\hline
\end{tabular}




\subsection{Groundwater QualityStatus}

The findings of [25] revealed that, groundwater suitability declines in the dry season than in the rainy season based on the four groundwater hazard classes (salinity, permeability/infiltration, specific ions toxicity and miscellaneous hazards) investigated. This is because irrigation is more intensive in the dry season with over exploitation of groundwater and intensive application of fertilizer in the soil due to the delay of on-set and short duration of rainfall period in the area. The order of dominance of groundwater quality class based on the result of Irrigation Water Quality Index (IWQI) model is: moderate $>$ good $>$ doubtful $>$ excellent (Figure 6). This suggests that, groundwater along the basin can be used for irrigation without much problem to soil, since the soils of the study locations have excellent to good permeability condition as shown by the results of indices of permeability/infiltration hazards (SAR, \%Na, KR, PI, MH). Similarly, vegetable crops can grow well as they have moderate tolerance to salt based on salinity hazard. However, overexploitation and intensive application of fertilizers can induce water quality deterioration. This problem can be worsened when the present permeability condition (good) of the soil also possess deterioration.

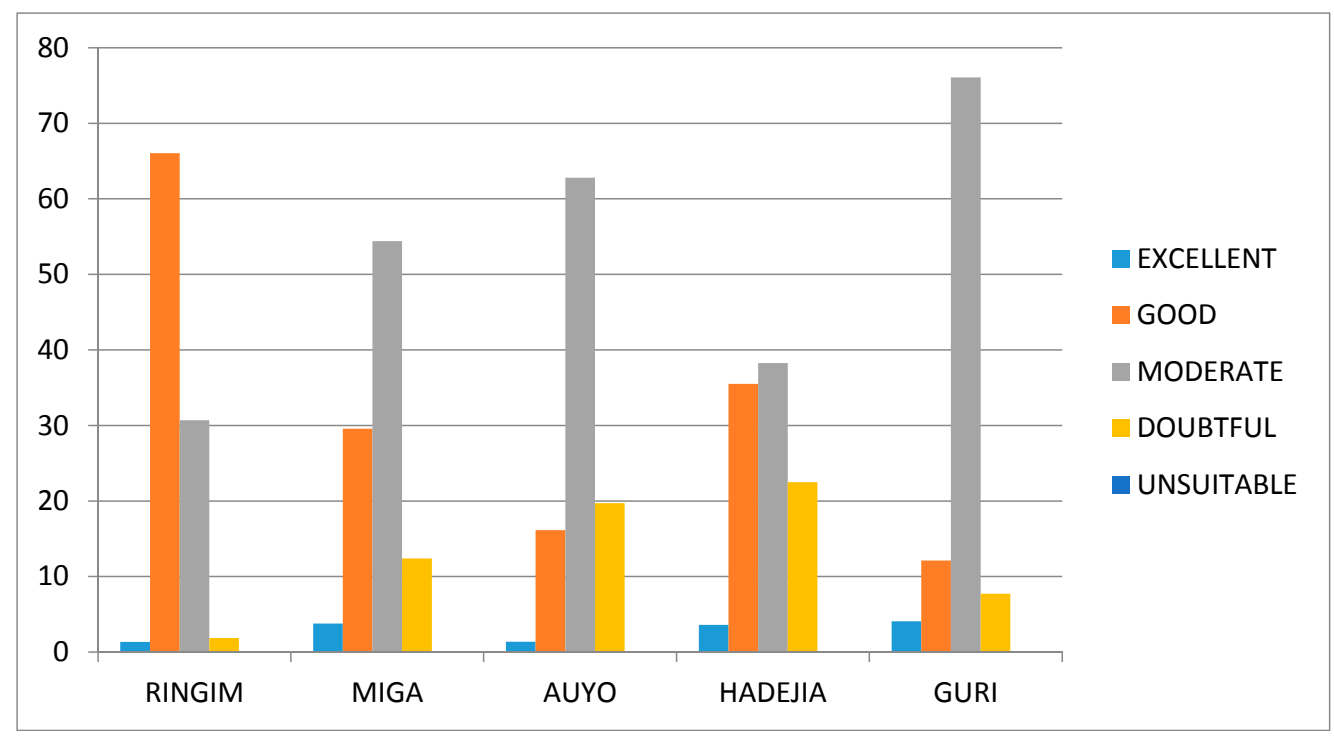

Figure 6. Suitability of fadama groundwater quality based on IWQI model along Hadejia River Basin.

\subsection{Recommended Management Strategies}

In view of the threat associated with the anticipated groundwater deficiency in the region and the apparent ineffective existing management options, the following management strategies are hereby proposed to enhance the conservation of the available groundwater resource for sustainable use.

\subsubsection{Managed Aquifer Recharge}

Manage Aquifer Recharge (MAR) is considered as one of the sustainable methods to manage groundwater resource especially in the dry land regions through artificial aquifer recharge (AAR). AAR has many advantages over conventional surface water storage such as dam construction especially in the basement complex area of Kano region. These advantages include negligible evaporation losses, limited vulnerability to secondary contamination by animals and or human and no algae blooms resulting in decreasing surface water quality. The flow of water through the subsurface provides soil-aquifer treatment (SAT), along with aquifers providing seasonal and/or longer storage. 


\subsubsection{Reclamation and Re-Use}

Water reclamation and re-use have become an attractive options for conserving and extending available groundwater resources especially in the dry land of the world, as urban areas in these regions approach and reach the limit of their available groundwater supplies. Reclamation and re-use techniques of wastewater can be adopted as an alternative to over-reliance on groundwater management especially in the southern Kano region where wastewater from municipal areas is common everywhere. This can be achieved through recharging groundwater with the reclaimed or recycled municipal wastewater. The purpose is to reduce, stop or even reverse declines of groundwater level. The treated water percolates through the soil mantle and unconfined aquifer, mix with native groundwater and eventually recovered and use again.

\subsubsection{Rainfall Harvesting}

Rainfall harvesting has been used as a supplementary or even primary water source for different uses especially in the semi-arid regions of the world where rainfall is sufficient only for short-season crops production. Rainwater harvesting provides a significant amount of freshwater in many countries with insufficient rainfall [20]. Examples include: Kuwait (12\% of the water demand for landscape agriculture); Muscat, Oman ( $27 \%$ of the water demand for industry); Abha, Saudi Arabia ( $11 \%$ of water demand for industry and landscape irrigation); and Ali Ain, United Arab Emirates (16\% of water demand for agriculture). In view of the successes made in other countries, the same management practice can be put in use in Kano region, especially in the Chad Formation area where geology and rainfall characteristics make surface water virtually unavailable. This can serve as an alternative source of surface water resource at household or small community level.

\subsubsection{Management of Wet Season Groundwater Excess}

Kano region is one of the dry land regions of Nigeria with known flood hazards. The region recorded 17\% of the total floods experienced in Nigeria during 2012 [48].Excess groundwater in the region occurs during the rainy season of the year when rainfall is heavy and the amount is sufficient to recharge the aquifers through soil infiltration of direct rainwater and seepage from rivers and their tributaries, especially in the Chad Formation region with high infiltration capacity. In this period, groundwater level rises to a higher level in the aquifer thereby increasing the quantity. This rising groundwater level is evident in most of the domestic wells both in urban and village areas of the region as well as in shallow tube wells of the floodplain. This wet season excess groundwater in the region often aids flooding, especially in the floodplains of Chad Formation region, leading to crop destruction that adversely impacts on farmers' livelihood. In view of the challenge of floodplain flooding resulting from excess groundwater and heavy rainfall, floodplain management is hereby recommended for managing wet season excess groundwater in the region.

\subsubsection{Floodplain Management}

Floodplain management is the operation of an overall programme of corrective and preventive measures for reducing flood damage, including, but not limited to, emergency preparedness plans; flood control works and floodplain management regulations. Floodplain management regulations were recognized as the most effective method for preventing future flood damage, especially in developing countries with known flood hazards [20]. Flood control measures both structural (flood control facilities) and nonstructural are used to regulate the flood runoff. Structural measures include reservoirs, diversions, levees or dikes and channel modifications, while nonstructural measures include flood proofing, flood early warning system and land use control. 


\section{Discussion}

Groundwater resources in Kano region were found to be migrating from southwest to the north eastern part of the region. A drop of about one half of shallow groundwater initial value was observed between 1964 and 1987. Evening hours recorded higher yield than morning hours.CA was also applied to the dynamic level data of groundwater across the sampling sites. The result is presented as a dendrogram in Figure 7, grouping all the five sampling sites into three statistically significant clusters: Cluster 1 (Guri), cluster 2 (Ringim), cluster 3 (Miga, Hadejia and Auyo). Guri and Ringim appeared to be in separate and independent clusters, meaning that, their groundwater dynamic level is significantly different. The reason that can be attributed to the fact that the groundwater dynamic level of Guri and Ringim is significantly differently from the others is because they are at the two extremes locations of the study area along the basin. In other words, Ringim is the first sampling site in the south western part of the basin in Kano State, while Guri is the last sampling site located in the extreme end (north east) of Jigawa State in the Chad Formation near Yobe State. The last cluster comprising of Miga, Hadejia and Auyo suggests that their groundwater dynamic levels are somewhat similar. Data collected from field work revealed that groundwater dynamic level increases with distance toward northeast along the basin. The result of CA supported the data collected. The fact that the CA result supports the collected data suggests that relying on sampling fewer CA sites for monitoring groundwater dynamic levels will not affect adversely the data gathered individually from more sampling sites. That is, one sample from the Hadejia-Miga-Auyo cluster and one each from the other two clusters would have yielded the same results as realized in this study from five sites. One of the implications is that groundwater decline will worsen the situation in the basement complex region which houses large proportion of the region's population. Consequently, groundwater deficiency is apparent in the southwestern part of the region which lies on igneous structure and access to water constitutes a great challenge because of the large population. Also, because the study area is among the dry (semi-arid) regions in Nigeria, which is characterized by prolonged dry season with high demand on groundwater for irrigation due to inadequate surface water availability, routine monitoring of groundwater availability and quality is very important. Such monitoring, principally the salinity condition has been recommended over three decades ago by the Macdonal and Diyam Consulting Company (Kano City, Kano State, Nigeria).

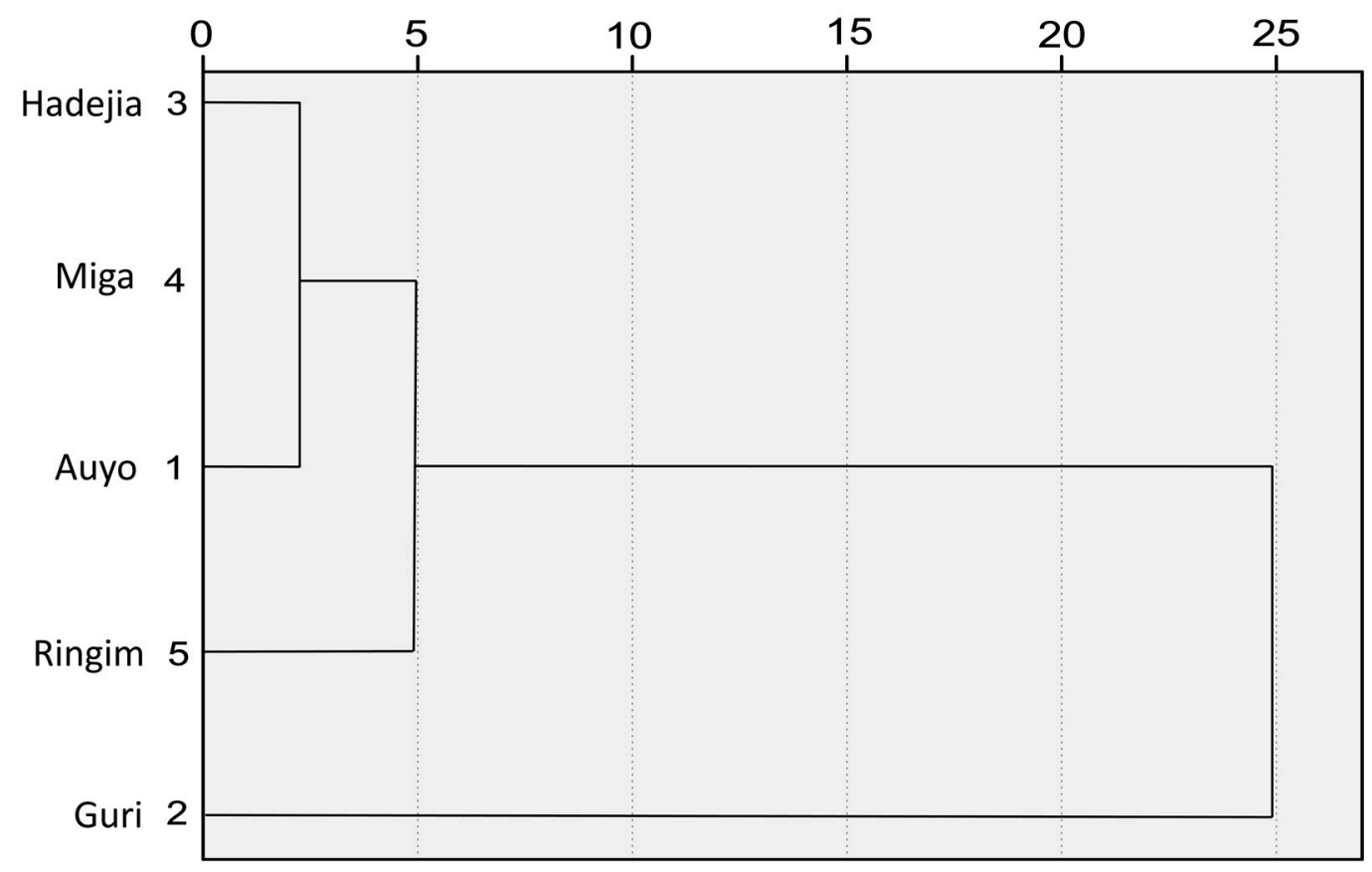

Figure 7. Dendrogram showing the cluster of sampling sites based on the groundwater dynamic levels along the basin. 
In view of the above findings and in addition to the recommended management strategies given for groundwater excess, deficiency and pollution minimization, this paper further recommends that government, donor agencies and other stake holders of the region should invest in scientific researches on groundwater in order to understand and come up with a reliable estimate of the available groundwater resource as well as to document up-to date time series data that can help in bridging the current existing gap in knowledge regarding the impact of climate variability and change on groundwater resource.

\section{Conclusions}

This paper reviews issues on groundwater management in Kano region and analyzed groundwater samples from selected fadama sites. The study revealed that groundwater resource availability varied between the Basement Complex and Chad Formation areas of the region, with the latter having more of the resource than the formerregion as a result of the migration of groundwater from the Basement complex to the Chad formation region as found by [16]. The study concludes that monitoring of groundwater dynamic levels is very important to sustainable floodplain irrigation. One other conclusion that arises from the study is that instead of gathering data for the exercise from many individual sites, the sites can be grouped into clusters of similar characteristics and a single sample from an appropriate site in a cluster will appropriately represent all the floodplain sites in the cluster. However, the review of existing practices revealed that there is poor knowledge regarding the impact of historical and projected climate variability and change on groundwater availability in the region as a result of the lack of sustained time series data on groundwater resource. Also, there has been little or no integrated management of water resources between times of groundwater excess and times of deficiency on one hand, and groundwater pollution management on the other hand. This study recommends, therefore that groundwater dynamic level monitoring should be undertaken regularly in order to generate time series data that can be used to undertake integrated groundwater management in the region. It is hoped that if these recommendations are adopted, the sustainability of groundwater resource can be achieved in Kano region.

Acknowledgments: We will like to thank Hadejia River Basin Development Authority, Kano, Nigeria for providing some of the hydrological data used in this paper. Also, we thank Tertiary Education Trust Fund, Nigeria, reference TETF/ES/AST\&D/UNIV/WUDIL for funding the data collection activities. Lastly, the authors sincerely thank Shehu Habibu of the Department of Chemistry, Federal University Dutse, Nigeria for improving the quality of figures used in this study. We also thank Andongma Wanduku Tende of the Department of Geology, Kano University of Science and Technology, Wudil, Nigeria for producing the land use map presented in this paper.

Author Contributions: Abubakar Ibrahim Tukur conducted the data collection activities in both the dry and rainy season and also drafted the manuscript together with Da'u Abba Umar. Aliyu Baba Nabegu and Emmanuel Ajayi Olofin vetted the manuscript and Wan Nor Azmin Suleiman provided access to scholarly articles that were reviewed through Perpustakaan Sultan Abdul Samad Library, University Putra Malaysia. All authors contributed to the writing of the manuscript.

Conflicts of Interest: No potential conflict of interest was reported by the authors.

\section{References}

1. Olofin, E.A. Geographical Hydrology, Lecture Notes on GEO 3214. In Introduction to Geographical Hydrology; Department of Geography, Bayero University: Kano, Nigeria, 2011; pp. 18-27.

2. The Millennium Development Goals Report. United Nations Newyork. Available online: http:/ /www.un. org/zh/millenniumgoals/pdf/MDGReport2006.pdf (accessed on 12 December 2016).

3. Kumar, M.; Kumari, K.; Ramanathan, A.L.; Saxena, R. A Comparative Evaluation of Groundwater Suitability for Irrigation and Drinking Purposes in two Intensively Cultivated Districts of Punjab, India. Environ. Geol. 2007, 53, 553-574. [CrossRef]

4. Nakoma, O.; Chidya, R.C.G.; Matamula, S.; Chawinga, C.B.J. Evaluation of Borehole Water Quality in Rural-Areas of Northern Malawi: Case of Zombwe in Mzimba. Phys. Chem. Earth 2016. [CrossRef]

5. Xu, Y.; Usher, B. Groundwater Pollution in Africa, 1st ed.; Tylor and Fransis Group plc: Leiden, The Netherlands, 2006. 
6. Ghana Statistical Service. Housing and Population Census Report; Ghana Statistical Service: Accra, Ghana, 2012.

7. Elisante, E.; Muzuka, A.N.N. Assessment of Sources and Transformation of Nitrate in Groundwater on the Slopes of Mount Meru, Tanzania. Environ. Earth Sci. 2016, 75. [CrossRef]

8. Akujieze, C.N.; Coker, S.J.L.; Oteze, G.E. Groundwater in Nigeria-A Millennium Experience-Distribution, Practice, Problems and Solutions. Hydrogeol. J. 2003, 11, 259-274. [CrossRef]

9. Tukur, A.I.; Garba, I.; Mustapha, A.; Umar, D.A.; Sulaiman, W.A.S. An Overview of Groundwater Quality Studies in Developing Countries. In Economic Diversification through Sustainable Mineral Resources Development, Proceedings of the 52nd Annual International Conference and Exbihition of the Nigerian Mining and Geosciences Society (NMGS), Ilorin, Nigeria, 13-18 March 2016; Kwara State NMGS: Ilorin, Nigeria, 2016.

10. Baba, A.; Tyfur, G. Groundwater Contamination and its Effect on Health in Turkey. Environ. Monit. Assess. 2011, 183, 77-94. [CrossRef] [PubMed]

11. World Health Organization (WHO) and World Water Assessment Programme (UNESCO-WWAP). Water for People-Water for Life; The United Nations, World Water Development Report; UNESCO Publishing: Paris, France, 2004.

12. Mays, L.W. Integrated Urban Water Management: Arid and Semi-Arid Regions; Tylor and Fransis Group plc: Leiden, The Netherlands; UNESCO Publishing: Paris, France, 2009; pp. 1-73.

13. Federal Republic of Nigeria. Central Bank of Nigeria Population Data; Federal Republic of Nigeria: Abuja, Nigeria, 2015.

14. Akinyemi, J.O.; Souley, S.O. Monitoring the Quality of Some Sources of Irrigation Water in Different Parts of Ogun State, Nigeria. IERI Procedia 2014, 9, 123-128. [CrossRef]

15. Olofin, E.A. Some Aspects of the Physical Geography of Kano Region and Related Human Responses; Departmental Lecture Note Series, No. 1; Department of Geography, Bayero University: Kano, Nigeria, 1987; pp. 1-58.

16. Abdulhamid, A. Drainage, Hydrology and Water Resources. In Kano: Environment, Society and Development, 1st ed.; Tanko, A.I., Momale, S.B., Eds.; Adonis and Abbey: London, UK; Abuja, Nigeria, 2014; Volume 1, pp. 21-34, ISBN 978190911291 (Paper Back), 9781909112407 (Hard Cover).

17. Tahir, A.G.; Garba, M.L.; Hamidu, I. Hydrogeology and Groundwater Quality of Deep and Shallow Boreholes in Kano Metropolis, Northwestern Nigeria. J. Environ. Earth Sci. 2015, 5, 160-166.

18. Abdulhamid, A.; Badamasi, M.M.; Muhammed, M.U. Dynamics of Rainfall Pattern and Groundwater Quantity in Kano Basement Complex: Evidence from Ground and Satellite Data. In Proceedings of the 1st International Conference on Drylands, Center for Dryland Agriculture, Bayero University, Kano, Nigeia, 8-12 December 2014; pp. 188-196.

19. Tukur, A.I. Evaluation of Groundwater Yield and Quality for Fadama Irrigation along Hadejia River Basin, Jigawa State, Northwestern Nigeria. Unpublished Ph.D. Thesis, Department of Geography, Bayero University, Kano, Nigeria, November 2017.

20. Mohammed, S.H. GIS-Based Modified Aquifer Modeling for Pollution Vulnerability Assessment in Kano, Nigeria. Unpublished Ph.D. Thesis, University Putra Malaysia, Selangor, Malaysia, April 2015.

21. Garba, A.; Ekanem, E.O.; Garba, I.H.; Mustapha, A. Multivariate Statistical Analysis of Groundwater Chemistry Data from Hadejia Local Government Area of Jigawa State, Nigeria. Glob. J. Adv. Res. 2016, 3, 713-722.

22. Sobowale, A.; Adewumi, J.K.; Otun, J.A.; Adie, D.B. Water Resources Potentials of Hadejia River Sub-Catchment of Komadugu Yobe River Basin in Nigeria. Agric. Eng. Int. CIGR J. 2010, 12, 1-9.

23. Adamu, G.K.; Tukur, R.; Kankara, A.I. Groundwater Quality Assessment in the Basement Complex Areas of Kano State Nigeria. Am. J. Eng. Res. 2013, 2, 171-175.

24. Umar, M.H. Analysis of Groundwater Fluctuation in Hadejia. Unpublished Master's Thesis, Department of Geography, Kano University of Science and Technology, Wudil, Nigeria, 2016.

25. Tasi'u, Y.R.; Igusi, E.O.; Malam, I. Assessment of Water Supply Situation in the Rural Areasof Kano State, Northern Nigeria. Glob. Adv. Res. J. Agric. Sci. 2016, 5, 33-41.

26. Rizwan, M.; Kulshreshtha, V.; Dev, P. Effects of Rainfall Factor on Hydrogeological System Recharge in Bangar Environs: A Middle Part of India. Bull. Pure Appl. Sci. 2017, 36, 27-43. [CrossRef]

27. Mastrocicco, M.; Colombani, N.; Salemi, E.; Castaldelli, G. Reactive Modeling of Denitrification in Soils with Naturaland Depleted Organic Matter. Water Air Soil Pollut. 2011, 222, 205-215. [CrossRef]

28. Colombani, N.; Osti, A.; Volta, G.; Mastrocicco, M. Impact of Climate Change on Salinization of Coastal Water Resources. Water Resour. Manag. 2016, 30, 2483-2496. [CrossRef] 
29. MacDonald, A.M.; Bonsor, H.C.; Dochartaigh, B.E.O.; Taylor, R.G. Quantitative Maps of Groundwater Resources in Africa. Environ. Res. Lett. 2012, 7. [CrossRef]

30. Taylor, R.G.; Koussis, A.D.; Tindimugaya, C. Groundwater and Climate in Africa-A review. Hydrol. Sci. J. 2009, 4, 655-664. [CrossRef]

31. Adewuyi, T.O.; Olofin, E.A. Spatio-Temporal Analysis of Flood Incidence in Nigeria and Its Implication for Land Degradation and Food Security. J. Agric. Sci. 2014, 6. [CrossRef]

32. Bakhari, A. Hydrochemical Assessment of Groundwater Quality in the Chad Basinaround Maiduguri, Nigeria. J. Geol. Min. Res. 2014, 6. [CrossRef]

33. Fagbote, E.O.; Olanipekun, E.O.; Uyi, H.S. Water Quality Index of the Groundwater of Bitumen Deposit Impacted Farm Settlements using Entropy Weighted Method. Int. J. Environ. Sci. Technol. 2013. [CrossRef]

34. Sheriff, A.; Obiefuna, G. Assessment of Shallow Ground Water Quality of Pindiga Gombe Area, Yola Area, NE, Nigeria for Irrigation and Domestic Purposes. Res. J. Environ. Earth Sci. 2011, 3, 131-141.

35. Obiefuna, I.G.; Orazulike, D.M. The Use of Anion Geochemistry in Mapping Groundwater Facies of Yola Area NE Nigeria. Res. J. Chem. Sci. 2011, 1, 130-141.

36. Adelana, S.M.A. Nitrate Pollution of Groundwater in Nigeria. In Groundwater Pollution in Africa, 1st ed.; Xu, Y., Usher, B., Eds.; Tylor and Fransis Group plc: Leiden, The Netherlands, 2006; p. 23.

37. Boukari, M.; Alassane, A.; Azonsi, F.; Dovonou, F.A.L.; Tossa, A.; Zogo, D. Groundwater Pollution from Urban Development inCotonou City, Benin. In Groundwater Pollution in Africa, 1st ed.; Xu, Y., Usher, B., Eds.; Tylor and Fransis Group plc: Leiden, The Netherlands, 2006; pp. 125-138.

38. Graham, W.B.R.; Pishiria, I.W.; Ojo, I.O. Monitoring of Groundwater Quality for Small-Scale Irrigation: Case Studies in the Southwest Sokoto-Rima Basin, Nigeria. CIGR J. 2006, 8, 1-9.

39. Mehra, M.; Oinam, B.; Singh, C.K. Integrated Assessment of Groundwater for Agricultural Use in Mewat District of Haryana, India Using Geographical Information System (GIS). J. Indian Soc. Remote Sens. 2016. [CrossRef]

40. Gereish, M.H.; Balke, K.D.; El-rayes, A.E.; Mansour, B.M. Implications of Climate Change on the Groundwater Flow Regime and Geochemistry of the Nile Delta, Egypt. J. Coast. Conserv. 2015, 19, 589-608. [CrossRef]

41. Sappa, G.; Ergul, S.; Ferranti, F.; Sweya, L.N. Effects of Seasonal Change andSeawater Intrusion on Water Quality for Drinking and Irrigation Purposes in Coastal Aquifers of Dar es Salaam, Tanzania. J. Afr. Earth Sci. 2015. [CrossRef]

42. Sharma, S.; Chippa, R.C. Interpretation of Groundwater Quality Parameter forSelected Area of Jaipur Using Regression and Correlation Analysis. J. Sci. Ind. Res. 2013, 72, 781-783.

43. Barbiero, L.; Neto, J.P.D.Q.; Ciornei, G.; Sakamato, A.Y.; Capellari, B.; Fernande, E.; Valles, V. Geochemistry of Water and Groundwater in the Nhecolandia, Pantanal of mato grosso, Brazil: Variability and Associated Processes. Wetlands 2002, 22, 528-540. [CrossRef]

44. American Public Health Association (APHA). Standard Methods for the Examination of Water and Wastewater, 1st ed.; American Public Health Association, American Water Workers Association, Water Environment Federation: Washigton, DC, USA, 2005; Volume 2.

45. Olofin, E.A. Water Resources Planning and Management: Lecture Notes on WMA 501. In Water Resources Planning and Management; Department of Water Resources Management and Agro-Meteorology, Federal University of Oye-Ekiti: Ikole, Nigeria, 2016; pp. 1-8.

46. Ayoade, J.O. Tropical Hydrology and Water Resources; Macmillan Publishers Ltd.: London, UK, 1988; p. 189.

47. Tanko, A.I. Water Resource Development and Management. In Kano: Environment, Society and Development, 1st ed.; Tanko, A.I., Momale, S.B., Eds.; Adonis and Abbey: London, UK; Abuja, Nigeria, 2014; Volume 1, p. 228, ISBN 978190911291 (Paper Back), 9781909112407 (Hard Cover).

48. Zuhair, A.; Nouh, M.; El Sayed, M. Flood Harvesting in Selected Arab States, Final Report No. M31/99, Institute of Water Resources. In Integrated Urban Water Management: Arid and Semi-Arid Regions; Mays, L.W., Ed.; UNESCO Publishing: Paris, France; Leiden, The Netherlands, 1999; p. 46.

(C) 2018 by the authors. Licensee MDPI, Basel, Switzerland. This article is an open access article distributed under the terms and conditions of the Creative Commons Attribution (CC BY) license (http:/ / creativecommons.org/licenses/by/4.0/). 